\title{
Genetic mapping of X linked ocular albinism: linkage analysis in British families
}

\author{
S J Charles, A T Moore, J R W Yates
}

\begin{abstract}
Genetic linkage studies were performed in 16 British families affected by $X$ linked ocular albinism (XLOA) using RFLPs from the $X p 22.3$ region. Linkage was confirmed between the XLOA locus (OA1) and the loci DXS143 (dic56; Zmax $=15.90$ at $\theta=0 \cdot 0$, confidence interval (CI) $0-0.035$, DXS85 (782; $Z \max =15.67$ at $\theta=0.04$, CI = 0.007-0.11), and DXS237 (GMGX9; $\mathrm{Zmax}=12.65$ at $\theta=0.08, \mathrm{CI}=0.03-0 \cdot 17)$. Multipoint linkage analysis placed $O A 1$ between DXS85 (782) and DXS237 (GMGX9) with odds exceeding 104:1 to give the map DXS85-(OA1,DXS143)DXS237-XG-Xpter. OA1 lies close to DXS143 (dic56) but in the absence of recombinants the order of these loci could not be determined.
\end{abstract}

$\mathrm{X}$ linked ocular albinism (XLOA) is a cause of reduced visual acuity and nystagmus in males ${ }^{1}$ and is associated with refractive errors, strabismus, iris translucency, fundus hypopigmentation, and foveal hypoplasia. ${ }^{2}$ The effects of the mutant gene are not confined to the eyes: visual evoked potentials show evidence of abnormal neuronal crossing at the optic chiasm ${ }^{3}$ and, although skin and hair pigmentation is normal, skin histology shows abnormal giant melanin granules termed macromelanoscomes $^{45}$ in all affected males. ${ }^{6}$

The vision of carrier females is normal, but ophthalmic examination shows a characteristic 'mud splattered' fundus appearance. ${ }^{7}$ Carriers may occasionally have a normal ophthalmic examination and several carriers are described with reduced visual acuity and nystagmus similar to an affected male. ${ }^{8-10}$ We have previously reported that $74 \%$ of obligate carriers have iris translucency and $84 \%$ have macromelanosomes on skin biopsy, but the most reliable sign of the carrier state is the characteristic 'mud splattered' fundus appearance with hyperpigmented streaks in the periphery seen in $92 \%$ of obligate carriers. ${ }^{6}$

The XLOA gene locus (OA1) was first localised to distal $\mathrm{Xp}$ by linkage to the $\mathrm{Xg}$ blood group. ${ }^{112}$ Tight linkage has been reported to $D X S 85(782),{ }^{1314}$ and other studies $^{1516}$ have shown linkage to markers in Xp22.3: DXS237, DXS278, DXS143, $D X S 452$. A family has been reported with $\mathrm{X}$ linked ichthyosis and XLOA, associated with a $3 \mathrm{Mb}$ deletion encompassing the steroid sulphatase gene and $D X S 237$, but not $D X S 143 .{ }^{17}$ This would be compatible with placing $O A 1$ distal to $D X S 143,15$ but not with another report placing $O A 1$ between $D X S 143$ and
$D X S 85{ }^{16}$ The precise positioning of $O A 1$ has therefore remained controversial.

In this study we report linkage analysis on 16 British families affected by XLOA using the DNA markers DXS237 (GMGX9), $D X S 143$ (dic56), and DXS85 (782).

\section{Patients and methods PATIENTS}

Sixteen multigeneration British families affected by XLOA were systematically assessed by an ophthalmologist (SJC). Within each kindred all available family members had a full ophthalmic examination, including assessment of best corrected visual acuity, ocular movements, colour vision (Ishihara and City University plates), slit lamp examination to assess iris translucency, and ophthalmoscopy. Where possible a skin biopsy was performed in each adult.

Primary diagnostic criteria for affected males were reduced visual acuity, iris translucency, hypopigmented fundi, macromelanosomes on skin biopsy, and a family history consistent with $\mathrm{X}$ linked inheritance. In all families at least one male met these criteria. Obligate carriers were diagnosed on the basis of having an affected father, or having an affected son plus an affected brother or other maternal male relative. Females at risk of having inherited the XLOA gene were only diagnosed as carriers and included in linkage analysis if the 'mud-splattered' fundus appearance with peripheral linear hyperpigmented streaks was present, with or without iris translucency. At risk females with an entirely normal ophthalmic examination were included as unaffected in the linkage analysis, but if ophthalmoscopy showed mild retinal pigment epithelial abnormalities they were excluded from the analysis. A total of 210 subjects was examined including 55 affected males, 48 obligate heterozygotes, and 60 'at risk' females. Venous blood samples were obtained from 192 subjects for DNA extraction and $\mathrm{Xg}$ blood grouping.

MOLECULAR STUDIES

DNA was tested for three RFLPs in the $\mathrm{Xp22.3}$ region using the DNA probes

Table 1 DNA probes used in the localisation of $O A 1$.

\begin{tabular}{lllcc}
\hline Locus & Probe & Enzyme & Alleles $(\mathrm{kb})$ & Reference \\
\hline DXS237 & GMGX9 & HindIII & 4.0 & 18 \\
& & & $2.5,1.5$ & 19 \\
DXS143 & dic56 & BclI & $\begin{array}{r}8.9 \\
7.4\end{array}$ & 19 \\
DXS85 & 782 & EcoRI & 14.0 & 20 \\
& & & 7.0 & \\
\hline
\end{tabular}

Cambridge University
Department of
Pathology, Tennis
Court Road,
Cambridge CB2 1QP.
S J Charles
J R W Yates
Department of
Ophthalmology,
Addenbrooke's
Hospital, Cambridge
CB2 2QQ.
S J Charles
A T Moore
Department of
Clinical Genetics,
Addenbrooke's
Hospital, Cambridge
CB2 2QQ.
J R W Yates
Correspondence to
Mr Charles FCOphth.
Received 9 December 1991.
Revised version accepted
30 January 1992.


Table 2 Two point linkage data between OA1 and DXS237, DXS143, DXS85, and the XG blood group locus.

\begin{tabular}{|c|c|c|c|c|c|c|c|c|c|}
\hline & \multicolumn{6}{|c|}{ Recombination fraction } & \multirow[b]{2}{*}{$\mathrm{Z} \max$} & \multirow[b]{2}{*}{$\theta \max$} & \multirow{2}{*}{$\begin{array}{l}\text { Confidence } \\
\text { interval }\end{array}$} \\
\hline & 0.00 & 0.01 & 0.05 & $0 \cdot 10$ & $0 \cdot 20$ & $0 \cdot 30$ & & & \\
\hline $\begin{array}{l}X G \\
D X S 237 \\
D X S 143 \\
D X S 85\end{array}$ & $\begin{array}{c}-\infty \\
-\infty \\
15 \cdot 90 \\
-\infty\end{array}$ & $\begin{array}{r}-6.33 \\
8.78 \\
15.63 \\
14.89\end{array}$ & $\begin{array}{r}-1.24 \\
12.29 \\
14.53 \\
15.61\end{array}$ & $\begin{array}{r}0 \cdot 51 \\
12 \cdot 60 \\
13 \cdot 12 \\
14 \cdot 73\end{array}$ & $\begin{array}{r}1.54 \\
10 \cdot 86 \\
10 \cdot 10 \\
11.85\end{array}$ & $\begin{array}{l}1 \cdot 44 \\
7 \cdot 86 \\
6 \cdot 88 \\
8 \cdot 27\end{array}$ & $\begin{array}{r}1.58 \\
12.65 \\
15.90 \\
15.67\end{array}$ & $\begin{array}{l}0 \cdot 24 \\
0 \cdot 08 \\
0 \cdot 00 \\
0 \cdot 04\end{array}$ & $\begin{array}{c}0.03-0.17 \\
0-0.035 \\
0.007-0.11\end{array}$ \\
\hline
\end{tabular}

GMGX9, dic56, and 782 (table 1). DNA extraction from blood (fresh and frozen) and Southern analysis were performed by standard techniques. ${ }^{21}$ Probes were labelled with ${ }^{32} \mathrm{P}$ and hybridised to Southern blots at $45^{\circ} \mathrm{C}$ in the presence of $50 \%$ (by volume) formamide, $5 \times$ SSC, $4 \times$ Denhardt's, $10 \%$ (by weight) dextran sulphate, and $0.1 \mathrm{mg} \mathrm{m}{ }^{-1}$ salmon sperm DNA. Filters were washed to a final stringency of 0.5 to $1.0 \times \mathrm{SSC}$ at $65^{\circ} \mathrm{C}$ and exposed to $x$ ray film for one to seven days at $-70^{\circ} \mathrm{C}$. Blood samples (EDTA) were also typed for Xg blood group (Dr Patricia Tippett, MRC Blood Group Unit, London).

\section{GENETIC LINKAGE ANALYSIS}

Linkage analysis was performed using two point $\left(\right.$ LIPED $^{22}$ ) and multipoint (LIN$\mathrm{KAGE}^{23}$ ) programs. OA1 gene frequency was estimated at 0.0001 . Confidence limits were determined as the values of the recombinant fractions at lod scores one unit below the maximum. For multipoint linkage analysis the marker order and map distances described by Yates et $a l^{4}$ were used and the map was constructed using the LINKMAP program of the LINKAGE package.

\section{Results}

The results of the two point linkage analysis are shown in table $2 . D X S 143$ is closely linked to $O A 1$ with a maximum lod score of 15.90 at zero recombination (confidence interval 0 0.035). Twelve families were informative for $D X S 143$. The peak lod score for DXS237 was 12.65 at 0.08 recombination (CI $0.03-0.17$ ) and for DXS85 the lod score was 15.67 at recombination fraction 0.04 (CI 0.007-0.11).

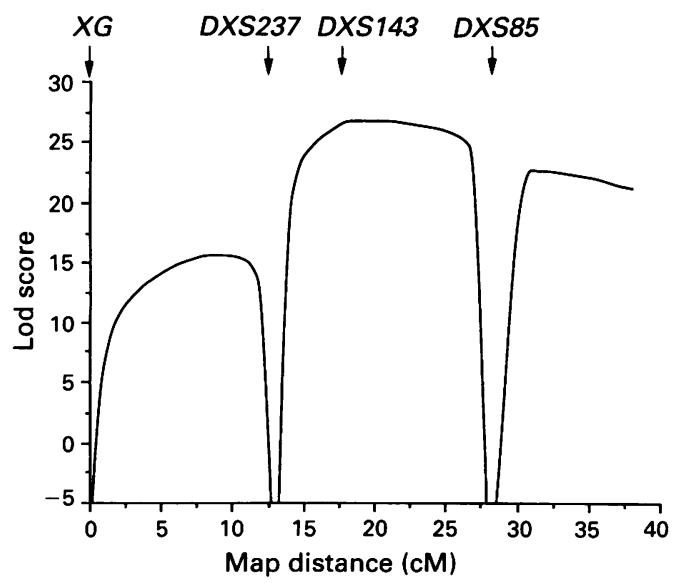

Multipoint linkage analysis with $O A 1$ and $X G$, DXS237(GMGX9), DXS143(dic56), and $D X S 85(782)$.
One family (CAM 4220) had a rare allele with GMGX9/HindIII, giving $2.5 \mathrm{~kb} / 1.6 \mathrm{~kb}$ fragments and showing mendelian inheritance and a recombinant with the disease. The smaller fragment could easily be distinguished from the usual $1.5 \mathrm{~kb}$ fragment of the $2.5 \mathrm{~kb} /$ $1.5 \mathrm{~kb}$ allele.

There were eight subjects contributing recombinants with $D X S 237$ or $D X S 85$. These comprised six affected males, one normal male, and one 'at risk' female with definite clinical signs of the carrier state.

Multipoint linkage analysis showed that the most likely location for $O A 1$ is in the $D X S 85-D X S 237$ interval (figure) to give the order DXS85-(DXS143,OA1)-DXS237-XGXpter. A location between DXS85 and DXS237 was at least $1.2 \times 10^{4}$ times more likely than in adjacent intervals. The peak multipoint lod score was 26.9 with $O A 1$ placed $1.2 \mathrm{cM}$ proximal to $D X S 143$ (dic56), but this score was not significantly higher than for positions distal to this marker. $O A 1$ lies close to $D X S 143$ but in the absence of recombinants the order of these loci could not be determined.

\section{Discussion}

This study confirms the localisation of the $O A 1$ locus to the $\mathrm{Xp} 22.3$ region. Previous studies have suggested that DXS85 (782) might be the most closely linked DNA marker with a cumulative lod score of 7.80 at zero recombination..$^{25}$ This study places $O A 1$ distal to $D X S 85$ at a recombination fraction of 0.04 with a maximum lod score of 15.67 and indicates that $O A 1$ may lie closer to $D X S 143$ (dic56). No recombinants were found between $O A 1$ and $D X S 143$. Analysis of recombinants in this study confirms localisation of $O A 1$ proximal to $D X S 237$ and distal to $D X S 85$, but absence of recombinants with $D X S 143$ does not allow further localisation about this locus. No family had more than one subject recombinant for the markers $D X S 237$ or $D X S 85$. There is therefore no evidence of genetic heterogeneity of XLOA in the British population.

Recombinants between $D X S 143$ and $O A 1$ have been reported but give conflicting information about the order. Bergen et al ${ }^{15} \mathrm{de}-$ scribed a normal male who was recombinant for $D X S 143$ but non-recombinant for $D X S 237$, placing $O A 1$ distal to $D X S 143$. Schnur et $a l^{16}$ reported an affected male who was recombinant for $D X S 143$ and distal markers, placing $O A 1$ proximal to $D X S 143$. Assuming correct diagnosis of XLOA in each study, these discrepancies are hard to explain. 
Normal males are unlikely to be misdiagnosed as having the condition and there are no reported cases of non-penetrance. Affected males may have visual acuity as good as $6 / 9$ without nystagmus, but foveal hypoplasia and iris translucency should not escape formal ophthalmic examination, as was reported in both studies. The recombinant of Bergen et $a l^{15}$ was uninformative for the locus proximal to $D X S 143$ so that a double crossover event cannot be excluded. Alternative explanations would be locus heterogeneity or a DNA typing error.

This study indicates that $O A 1$ is closely linked to the $D X S 143$ locus and multipoint analysis slightly favours the order $X G$ $D X S 237-D X S 143-O A 1-D X S 85$ over the order XG-DXS237-OA1-DXS143-DXS85, but the difference is not significant. Further linkage data are required to order $O A 1$ precisely with respect to $D X S 143$ and other loci in this region.

SJC is in receipt of a Wellcome Vision $\mathrm{Re}$ search Fellowship. The authors thank those clinicans who have referred cases, especially Dr S Bundey, Dr B C Davison, Professor J Edwards, Professor B Jay, Dr M Jay, and Dr M Super; Dr D Barton for technical assistance; Dr P Tippett for Xg blood group typing; and the families who cooperated so willingly in this study.

1 Nettleship E. On some hereditary diseases of the eye. Tran Ophthalmol Soc UK 1909;29:57-198.

2 Kinnear PE, Jay B, Witcop CI. Albinism. Surv Ophthalmol 1985;30:75-101.

3 Creel D, O'Donnell FE Jr, Witcop CJ Jr. Visual system anomalies in human ocular albinos. Science 1978;201:931 3 .

4 O'Donnell FE, Hambrick GW, Green WR, et al. X linked ocular albinism. An oculocutaneous macromelanosomal disorder. Arch Ophthalmol 1976;94:1883-92.

5 Garner A, Jay BS. Macromelanosomes in X-linked ocular albinism. Histopathology 1980;4:243-54.

6 Charles SJ, Moore AT, Grant JW, Yates JRW, Genetic counselling in X linked ocular albinism: clinical features of the carrier state. Eye 1992;6:75-9.
7 Falls HF. Sex-linked ocular albinism displaying typical undus changes in the female heterozygote. $\mathrm{Am} \mathrm{f} O \mathrm{Oph}$ thalmol 1951;34:41-50.

8 Gillespie FD, Covelli B. Carriers of ocular albinism with and without ocular changes. Arch Ophthalmol 1963;70:209-13.

9 Pearce WG, Johnson GJ, Gillan JG. Nystagmus in a female carrier of ocular albinism. $f$ Med Genet 1972;9:126-8.

10 Jaeger C, Jay B. X-linked ocular albinism: a family containing a manifesting heterozygote, and an affected male married to a female with autosomal recessive ocular married to a female with autosomal

11 Fialkow P, Giblett ER, Motulsky AG. Measurable linkage between ocular albinism and $\mathrm{Xg}_{\mathrm{g}} \mathrm{Am} \mathcal{F} \mathrm{Hum}$ Genet 1967;19:63-9.

12 Pearce WG, Johnson GJ, Sanger R. Ocular albinism and Xg. Lancet $1971 ; \mathbf{i}: 1072$.

13 Kidd JR, Castiglione CM, Davies KE, et al. Mapping the locus for X-linked ocular albinism. Am $\mathcal{f}$ Hum Gene 1985;37(suppl):161A.

14 de Martinville B, Graham JM, Risdahl JS, et al. Genetic analysis in X-linked ocular albinism. Cytogenet Cell Genet 1987;46:605-6.

15 Bergen AAB, Samaans C, van Dorp DB, et al. Localisation of the X-linked ocular albinism gene (OA1) between DXS278/DXS237 and DXS143/DXS16 by linkage analysis. Ophthalmol Paediatr Genet 1990;11:165-70.

16 Schnur RE, Nussbaum RL, Anson-Cartwright L, et al. Linkage analysis in X-linked ocular albinism. Genomics 1991;9:605-13.

17 Schnur RE, Trask BJ, van den Engh G, et al. An Xp22 microdeletion associated with ocular albinism and ichmicrodeletion associated with ocular albinism and ichdeletion size by using cloned DNA probes and flow cytometry. Am ₹ Hum Genet 1989;45:706-20.

18 Gillard EF, Affara NA, Yates JRW, et al. Deletion of a DNA sequence in eight of nine families with $\mathrm{X}$-linked ichthyosis (steroid sulphatase deficiency). Nucleic Acids Res 1987;15:3977-85.

19 Middlesworth W, Bertelsen C, Kunkel LM. An RFLP detecting single copy $\mathrm{X}$ chromosome fragment, dic56, from Xp22-Xpter. Nucleic Acids Res 1985;13:5723.

20 Hofker MH, Wapenaar MC, Goor N, Bakker E, van Ommen GJB, Pearson PL. Isolation of probes detecting restriction fragment length polymorphisms from $X$ chro restriction frafic librich mosome-specific libraries. potential use for diagnosis of D6.

21 Maniatis T, Fritsch EF, Sambrook J. Molecular cloning: a laboratory manual. Cold Spring Harbor, NY: Cold Spring laboratory manual. Cold Spri

22 Ott J. Estimation of the recombination fraction in human pedigrees: efficient computation of the likelihood for human linkage studies. Am f Hum Genet 1974;26:588-97.

23 Lathrop GM, Lalouel JM, Julier C, Ott J. Multilocus linkage analysis in humans: detection of linkage and estimation of recombination. Am $\mathcal{f}$ Hum Genet 1985;37:482-98.

24 Yates JRW, Goudie DR, Gillard EF, et al. Multipoin linkage analysis of steroid sulphatase (X-linked ichthyosis) and distal Xp markers. Genomics 1987;1:52-9.

25 Keats B, Ott J, Conneally M. Report of the committee on linkage and gene order. Human Gene Mapping 10. Cytogenet Cell Genet 1989;51:459-502. 